\title{
Title: Twacha and its relation with Dosha-Dhatu-Mala- a review
}

\section{Authors: Umarkar Suwarna Vasantrao*1, Deepak M. Vyas ${ }^{2}$}

1. Assistant Professor in Dept. Kriya Sharir, Govt. Ayurved College, Nagpur

2. Associate Professor in Dept. Kriya Sharir, Jupiter Ayurved Medical College, Nagpur. Mobile: 9404554773; Email: dr.deepakmvyas@ gmail.com

*Corresponding Author: Mobile: 9423404273; Email: dr.suwarnavumarkar@ gmail.com

\section{Abstract:}

Ayurveda is the science of life. It is a comprehensive system of health care. The Fundamental concepts of Ayurveda are systematized in classical texts like Bruhatrayi and Laghutrayi. A Healthy skin (Twacha) is a source of pleasure not only to its owner but also to one who looks at it. Twacha regulates cellurand molecular interactions and governs many crucial responses to our environment. Because* of its visibility Twacha reflects one's emotions and some aspects of normal physiology. A slight change in its colour might be an indication towards the homeostatic imbalances in the body. Dosha Dhatu and Mala play a vital role in maintaining Twacha Swasthya .So in present article it is an attempt to study concept of Twacha and its relation with Dosha Dhatu and Mala.

Keyword:

Twacha, Panchamahabhuta, Dhatu, Dosha, skin

\section{Introduction:}

Twacha is one of the 'Gyanindriyas' which is responsible for 'Sparsha Gyan' therefore it plays a great role in physical and mental well being of any individual. The Unbroken skin is the nature's dressing over the body. The word Twacha is derived from "Twak Savarne"
Dhatu which means the covering of body. According to Vachaspatyam, covering of the body is called as Twacha (1). The Entire Shadangas remains covered by the Twacha (2). Charaka described Twacha as the Matruja Bhava. (3) There are six factors which are responsible for the formation of Garbha. Twacha is formed 
and nourished by Matruja Bhava. In present review here is an attempt to explore concept of Twacha with its theory of Utpatti, types, Panchabhautiktwa, Twacha Karya and its relation with Dosha Dhatu and Mala.

\section{Aims_and_Objects:}

1. To study concept of Twacha through Samhita granthas

2. To study relation of Twacha with Dosha-Dhatu-Mala

\section{MATERIAL AND METHOD}

Literature collection will be done from Bruhatrayi and Laghutrayi.

\section{LITERATURE REVIEW}

According to Charaka the six layers of Twacha is formed from Mamsa Dhatu. Nutrients coming from Poshake Mamsa Dhatu are acted upon by Mams Dhatwagni and Poshya Mamsa is formed along with Upadhatu Vasa and six layers of Twacha. (4).Sushruta described the process of formation of Twacha in the context of fetus development. When the fertilization takes place the fetus develop rapidly through the process of transportation. Each and every molecule is involved in this process. The formation of seven layers of the Twacha exhibits in the similar manner as the different layer of the cream formed on the surface of boiled milk occurs. (5) This suggests that Twacha develops initially in the Garbha and inside it all other organ develop. According to Sushruta after fertilization of ovum Twacha develops just like a cream on the surface of milk.

In the uterus during the course of development of Garbha, differentiation of the layers of the skin takes place and is produced by all three Doshas, particularly by the Pitta Dosha. Twacha develops consecutively in seven layers by the synchronized peculiar action of Dosha. Vagbhata described the formation of Twacha due to Paka of Rakta Dhatu by its Dhatvagni in the fetus. After Paka, it dries up to form Twacha, just like the deposition of cream over the surface of boiled milk. (6) Vruddha Vagbhata has asserted that Rakta Dhatu plays principle role in the manifestation of Twacha. (7) While commenting on verse Indu has elucidated that metamorphosis of Rakta by its own Ushma result in accomplishment of all the layers of Twacha. According to Bhavmishra Twacha is formed by Pachan of Shukra and Rasa Dhatu. (8)

Twacha Utpatti Kala is different ccording to different Samhita. According Yagyavalka Smruti Twacha is formed in th month of foetal life. According to Vagbhatta (9) it formed in $6^{\text {th }}$ month of foetal life. Charaka (10) opinises that Mamsa Dhatu Vruddhi occurs in $5^{\text {th }}$ month of fetal life and Varna Utpatti at $6^{\text {th }}$ month so formation of Twacha will be completed up to $6^{\text {th }}$ month of fetal life. As per modern medical science all layers of epidermis is formed in $4^{\text {th }}$ month of intrauterine life. Process of keratization is seen at 23 weeks. Twacha is mentioned as Upa Dhatu of Mamsa Dhatu by all Acharya except Sharangdhara. (11) Nourishment of Twacha is achieved through essence of Mamsa Dhatu. Mamsa Peshi covers Sira, Snayu, Asthi, Sandhi and other organ of body. Aachadana Karma of Twacha is identical with Mamsa Dhatu. Twacha is mentioned as a Mala of Majja Dhatu (12) 
Table No. 1 Twacha Layers According To Different Acharya

\begin{tabular}{|l|l|c|}
\hline S.No & Acharya & Layers \\
\hline 1 & Charaka & 6 \\
\hline 2 & Sushruta & 7 \\
\hline 3 & $\begin{array}{l}\text { Vagabhat has not given any description; } \\
\text { Arundatta and Hemandri (Same as Sushruta) }\end{array}$ & 7 \\
\hline 4 & $\begin{array}{l}\text { Sharangdhara- (First 6 layers same as Sushruta but the seventh layer is } \\
\text { named as Sthula. It is the site of Vidradhi. }\end{array}$ & 7 \\
\hline 5 & \begin{tabular}{l} 
Kashyapa, Bhel \\
\hline 7
\end{tabular} & Bhavprakash \\
\hline
\end{tabular}

Table No. 2 Name of various Twacha layers according to different Acharya

\begin{tabular}{|l|c|c|c|c|c|c|}
\hline \multicolumn{1}{|c|}{ Charaka } & Sushrut & $\begin{array}{c}\text { Ashtang } \\
\text { Hrudaya }\end{array}$ & $\begin{array}{c}\text { Asthang } \\
\text { Samgraha }\end{array}$ & Sharag- & Bhel & Bhav \\
Udakdhara & Avbhasini & Prathama & Avbhasini & Avbhasini & Udakdhara & Avbhasini \\
\hline Asrugdhara & Lohita & Dwitiya & Lohita & Lohita & Asrugdhara & Lohita \\
\hline Thrutiya & Sweta & Thrutiya & Sweta & Sweta & Thrutiya & Sweta \\
\hline Chaturti & Tamra & Chaturti & Tamra & Tamra & Chaturti & Tamra \\
\hline Panchami & Vedini & Panchami & Vedini & Vedini & Panchami & Vedini \\
\hline Shasti & Rohini & Shasti & Rohini & Rohini & Shasti & Rohini \\
\hline & Mamsadhara & & Mamsadhara & Stula & & Stula \\
\hline
\end{tabular}

\section{(A) Twacha as per Charaka}

Charaka has described six layers of Twacha but he has named only two layers of Twacha. The rest four layers have been described in terms of the diseases. (2)
1) First, most outer layer is known as Udakadhar'. It is concerned with regulation of water balance.

2) Second layer is known as Asrugdhara as it has rich source of blood. 
3) Third layer is the site for the manifestation of Sidhma and Kilasa. These are the diseases in which the Varna gets changed mainly. So, this layer of the skin can be considered as the site of Varna.

4) Fourth layer is the site for the manifestation of Dadru and Kushtha

5) Fifth layer is the site for the manifestation of Alaji and Vidradhi.

6) Sixth layer is that by the excision of which the individual gets trembling and enters into darkness like a blind man. Boils of joints which are blackred in color and having thick root are manifested in this layer. Such boils are extremely difficult for treatment.

\section{(b) Twacha as per Sushruta}

Sushruta has described seven layers of Twacha along with the specific names. He has also mentioned the thickness of each layer along with the diseases which are prone to that layer. (5)

Table 3 Various Twacha layers, Thickness and Vyadhi site

\begin{tabular}{|l|l|l|l|}
\hline S.no & Name & Thickness & Name of Vyadhi \\
\hline 1 & Avbhasini $^{\#}$ & $1 / 18$ Yava & Sidhma, Padmakantaka \\
\hline 2 & Lohita & $1 / 16$ Yava & Tilakalaka, Nyacha, Vyanga \\
\hline 3 & Sweta & $1 / 12$ Yava * Ca & Cadala, Ajagalli, Mashaka \\
\hline 4 & Tamra & $1 / 8$ Yava & different types of Kilasa, Kushtha \\
\hline 5 & Vedini & $1 / 5$ Yava & Kushtha, Visarpa \\
\hline 6 & Rohini & 1 Yava & Granthi, Arbuda, slipada, Galaganda. \\
\hline 7 & Mamsadhara & 2 Yava & Bhagandara, Vidradhi, Arsha \\
\hline
\end{tabular}

\# Manifests all the Varnas and highlights the five types of Chaya. Chaya circumscribes the Varna and can be observed only from nearby (13). Disease in which Varna gets changed mainly. So this layer can be considered as the site of Varna but Varnas is manifested through the Avabhasini layer.

(c) Vrudha Vagabhatta has stated six layers of skin and named the layers according to Charaka except the six layers. He named this layer as Pranadhara. (6)

(d) Vagabhatta has described seven layers of skin similar to Sushruta but he has not given any description. Commentator Arundatta and Hemadri have named them according to Sushruta.

(e) Sharangdhara has also mentioned seven layers of skin along with the probable onset of diseases. The names of 
first six layers are same as Sushruta but the seventh layers is named as "Sthula" which is the site of Vidradhi. (14)

(f) Bhel- Bhel agree with the description given by Charkacharya about the layers of skin (15)

Panchabhautiktwa of Twacha:Stula, Stira and Murtimant Guna is due to Prithvi Mahābhuta. Mrudu, Snigha Twacha is due to Apya Mahabhuta. Teja Mahabhuta is responsible for Varna of skin. Vayu Mahabhuta is responsible for sensation of pain, temperature and pressure. The Pores of Loma and Swedavaha Strotas are due to Aakash Mahabhuta. Twacha is mainly Parthiva but also shows characters of other Mahabhuta. (16) (17)

\section{Twacha Karya}

1) Aavarana (18)- Twacha covers th whole body thus protect it from various external bacteria

2) Lepana (19)- It is most important function of Mamsa Dhatu. Twacha is UpaDhatu of Mamsa Dhatu.

3) Sparshagyan (20)- Twacha serves as Indriya Adhistana. It is important sense organ. No sensation can occur without a sense of touch. It is Sarvasrya Adhisthana.

4) Prakashan (21)-Twacha is the site of Bhrajaka Pitta and this is responsible for Varna as Gaura and Krishna.

5) Pachan- Twacha is site for Bhrajak Pitta so any Lepa application on Twacha get absorbed and performs its function.

6) Dharana- Twacha performs its Dharana function by holding water capacity in it.
7) Mala Nirharan -The convergence of Sweda occurs through Swedavaha Strotasa which opens on Twacha; hence, it is an important organ of excretion for Sweda and Mala.

8) Ushma Niyantrana- Through the mechanism of perspiration it also regulate the temperature of body. So it is an important organ for heat regulation.

\section{Relation of Twacha with Dosha - Dhatu} - Mala

\section{Relation with Dosha}

Twacha are one of the sites of Vata Dosha. It has been considered as Sparshnendriya Adhistana (22) So relation of Vata Dosha with touch sensation is established. Varna of Twacha is the function of Udan Vayu. (23) Transport and excretion of sweat is under control of Samana and Vyana Vayu respectively. Twacha is one of the sites of Pitta dosha. Pitta situated in skin is known as Bhrajak Pitta which gives colour and luster to the skin. Different skin applications are digested and absorbed through skin due to Bhrajaka Pitta. Thermoregulatory function of skin is maintained by Bhrajak Pitta. (24) Udaka karma of Kledaka Kapha means to keep the adequate moisture in Twacha. Snigdhata, Shlakhshanta, Mruduta, Sheetata, Prasannata of Twacha is the due to Kapha Dosha and Kapha is responsible for Ropan Karma. (25)

\section{Relation of Twacha with Dhatu}

Rasa is Apya. It keeps skin fresh as first exhibition of water content of body is always on skin. Person with Uttam Rasa Sarata (Twak Sarata) has best quality of Twacha and Loma which has already 
mentioned. (26) Varna Prasadan function is performed by Rakta Dhatu. (27) Mulasthan of Mamsavaha Strotas is Twacha and also Upadhatu of Mamsa Dhatu is Twacha. Function of mamas Dhatu and Twacha is same that is to cover or lepana. The principle function of Mamas Dhatu is covering. (28)

\section{Relation of Twacha with Mala}

Twacha is the important excretory organ. Khamala is mala of Mamsa Dhatu. Sweda is Mala of Meda Dhatu which is excreted by Twacha. Sweda maintains the luster and humidity of Twacha. Twakgat Sneha is the Mala of Majja Dhatu. (29)

Charakaacharya has described that Twacha is Mula Sthana of Mamsavaha Strotas and Lomkupa is the Mula Stana of Swedavaha Strotas (30) Twacha is one out of five sense organs like eyes, ears, nose tongue and skin. Twacha is Adhistan Sparshanendriya. Twacha is also called as Sarvashraya. Twacha looks fresh with soft hair on skin is the Lakshana of Rasa Sara person (31) Well nourished Twacha is characterized by unctuous, smooth, soft, clear, fine, less numerous, deep rooted, tender hair and lustrous Twacha. Such individual are endowed with happiness, good future, power, enjoyment, intellect, knowledge, health, excitement and longetivity. (32) Twacha has different characteristics according to dominant Dehaprakriti. Twacha and Loma of Vata Prakriti person are rough due to Ruksha Guna. Due to Vaishadya Guna Sputitavayav is also seen in Vata Prakriti person. Pitta Prakriti, person has Gaur Varna and Kapil Varna Loma. Prabhuta Tilpittka and Prabhut Swedapravritti is also seen in Pitta Prakriti volunteers.
Kapha Prakriti person has Snigdha twacha, Mruduanga and Alpa Sweda Praman. (33)

\section{Discussions and Conclusion:}

Twacha is Matruj Avayav which covers body. It is Upadhatu of Mamsa Dhatu which give rise to Vasa and six layers of Twacha. It is external covering of body which is the site of Sparsha Ghyanendriya, Swedavaha Strotas and Romakupa. Nourishment of Twacha is derived through essence of Mamsa Dhatu. Twacha is also mentioned as Mala of Majja Dhatu. Different Aacharyas have mentioned various layers of Twacha which varies in name and number but their functions are same. Twacha is one of the sites For Vata Dosha. Varna of Twacha is the function of Udan Vayu. Bhrajaka Pitta situated in the Twacha which gives olour and luster to the skin. Different applications are absorbed and digested through Twacha due to Bhrajaka Pitta. Adequate moisture or Mruduta is also maintained in the Twacha due to Udaka Karma of Kledaka Kapha. Varna Prasadan Karma is also performed by Rakta Dhatu Twacha is the important excretory organ. Khamala is mala of Mamsa Dhatu. Sweda is Mala of Meda Dhatu which is excreted by Twacha. Sweda maintains the luster and humidity of Twacha. Person of Uttam Twak Sarata has best quality of Twacha. Twacha has different quality according to dominant Deha Prakriti. Twacha and Loma of Vata Prakriti person are rough due to Ruksha Guna. Due to Vaishadya Guna Sputit Avayav is also seen in Vata Prakriti person. Due to Ushna Guna of Pitta Prakriti, person has fair skin colour. Mrudu, Alpa, Kapil Varna Loma. He has 
Tamrapanipadital and Prabhuta Tilpittka.

Prabhut Sweda Pravritti is also seen in Pitta Prakriti volunteers. Due to Snigdha Guna of Kapha this Prakriti person has fair colour skin. Kapha Prakriti person has Mrudu Anga and Alpa Sweda Praman.

\section{References:}

1. Tarkvachaspati Vachaspatyam.

T. In Chaukhambha 1990. p. 3401.

2. Agnivesha, Charak Samhita, Drudhabala. Sharirsamkhyasharir. In Shukla V, Tripathy R, editors. Charak Samhita. 2nd ed. Varanasi: Choukhambha Sanskrit Pratisthan; 2000. p. 763.

3. Agnivesha, Charak, Drudhabala. Khuddikagarbhavkranti. In Shukla V, Tripathy R, editors. Charak Samhita. 2nd ed. Varanasi: Chaukhambha Sanskrit Pratisthan; 2000. p. 717.

4. Agnivesha, Charak, Drudhabala Grananidoshachikitsa. In Shukla V, Tripathy R, editors. Charak Samhita. 2nd ed. Varanasi: Chaukhambha Sanskrit Pratisthan; 2002. p. 361.

5. Sushrut. Garbhavyakaransharir. In Shastri A, editor. Shushrut Samhita. Varanasi: Choukhambha Sanskrit Samsthan; 2005. p. 28.

6. Vagbhatta. Angavibhagsharir Adyay. In Tripathy B, editor. Astanga Hrudayam. New Delhi: Choukhmbha Sanskrit Series; 2012. p. 367.

7. Tripathy R, editor. Angavibhagsharir. In Astang Samgraha. New Delhi: Chaukhmbha Sanskrit Pratisthan; 2003. p. 476.

8. Mishra B. In Shastri B, editor. Bhavaprakash Purva Khanda. Varanasi: Choukhambha Sanskrit Samsthan; 1999. p. 33.
9. Vagbhatta. Garbhavkrantisharir. In Tripathy B, editor. Astanga Hrudayam. New Delhi: Choukhmbha Sanskrit Samsthan; 2012. p. 348.

10. Agnivesha, Charak, Drudhabala. Mahatigarbhavkranti. In Shukla V, Tripathy R, editors. Charak Samhit. 2nd ed. Varanasi: Chaukhamba Sanskrit Pratisthan; 2000. p. 732.

11. Agnivesha, Charak, Drudhabala. Grahanidoshachikitsa. In Shukla V, Tripathy R, editors. Charak Samhita. Varanasi: Chaukhambha Sanskrit Pratisthan; 2002. p. 364.

12. Agnivesha, Charak, Drudhabala. Grahanidoshachikitsa. In Shukla V, Tripathy R, editors. Charak Samhita. Varanasi: Chaukhambha Sanskrit Pratisthan; 2002. p. 764.

13. Agnivesh , Charak, Drudhabala. Pannrupiyamindriyaaadhyaya. In Shukla V, Tripathy R, editors. Charak Samhita Indriya Sthan. 2nd ed. Varanasi: Chaukhambha Surbharti Pratisthan; 2000. p. 841.

14. Mishra S. Kaladikaaakhayanam. In Sharangdhar Samhita. p. 59.

15. Shukla GD, editor. Sharirsamkhyasharir. In Bhel Samhita. Varanasi: Chaukhambha Bharati Acadamy; 2006. p. 69.

16. Agnivesha , Charak, Drudhabala. Sharir Samkhya Sharir. In Shukla V, Tripathy R, editors. Charak Samhita. 2nd ed. Varanasi: Chaukhambha Samskrit Pratisthan; 2000. p. 770.

17. Sushrut. Sarvabhutachintasharir. In Shastri A, editor. Sushrut Samhita. Varanasi: Chaukhambha Sanskrit Samsthan; 2005. p. 7.

18. Agnivesh, Charak, Drudhabala. Saamkhyasharir. In Shukla V, Tripathy R, editors. Charak Samhita. 2nd ed. Varanasi: Chaubhambha Sanskrit Pratisthan; 2002. p. 761.

19. Vartak SG. In Dosha Dhatu Mala Vigyan. Satara: Marashtra Rajkiya 
Ayurvedic

Anusandhan

Samity,Pradnya Press ; 1962.

20. Sushruta. In Shastri A, editor. Sushruta Samhita. Varanasi: Chaukhambha Sanskrit Samsthan; 2005. p. 31.

21. Shastri A, editor. shukrashonitashuddhisharir. In Sushruta Samhita sharirsthan. Varanasi: Chaukhambha Sanskrit Samsthan; 2013. p. 19-20.

22. Tripathy B, editor. Doshabhediya. In Astangn Hrudayam. New Delhi: Choukhmbha Sanskrit Samsthan; 2012. p. 170.

23. Agnivesha, Charak, Drudhabala. Vatavyadhi Chikitsa. In Shukla V, Tripathy R, editors. Charak Samhita.; 2002. p. 688.

24. Sushrut. Vranaprashna. In Trikamaji Y, editor. Sushruta Samhita with Nibandhasangraha. Varanasi: Chaukhamba Sanskrit Pratistan; 2003. p. 101.

25. Sushruta. Vranaprashna. Shashtri A, editor. Sushru Samhita. Varanasi: Chaukhamba Sanskrit Sanstan; 2005. p. 90.

26. Agnivesha, Charak, Drudhabala. Rogbhishagjitiyaviman. In Shukla V, Tripathy R, editors. Charak Samhita. Varanasi: Chaukhambha Sanskrit Pratisthan; 2000. p. 103.

27. Sushrut. Doshadhatumala kshayavruddhivigyaniya. In Shastri A, editor. Sushrut Samhita.
Varanasi: Chaukhambha Sanskrit Pratisthan; 2005. p. 57.

28. Agnivesha, Charak, Drudhabala. In Shukla V, Tripathy R, editors. Chark Samhita. 2nd ed. Vaaranasi: Chaukhanbha Sanskrit Pratisthan; 2000. p. 588.

29. Vagbhatta.

Angavibhagshariradhyaya. In TRipathy B, editor. Astanag Hrudayam. New Delhi: Choukhmbha Sanskrit Samsthan; 2012. p. 379.

30. Agnivesha, Charak, Drudhabala. Strotovigyanviman. In Shukla V, Tripathy R, editors. Charak Samhita. 2nd ed. Varanasi: Chaukhambha Sanskrit Pratisthan; 2002.

31. Sushruta. Aaturopkramaniya. In Sushruta Samhita. Varanasi: Chaukhambha Sanskrit Sansthan; 2005. p. 132.

32. Agnivesha, Charak, Drudhabala. Rogbhishagjitiyaviman. In Shukla V, Tripathy R, editors. Charak Samhita. 2nd ed. Varanasi: Chaukhambha Sanskrit Pratisthan; 2002.

33. Umarkar SV. The study of skin according to different Deha Prakriti with certain Ayurvedic, Biophysical, Biochemical and Microbial parameters. 2017. MUHS Nasik.

\section{Cite article:}

Twacha and its relation with Dosha-Dhatu-Mala- a review

Umarkar Suwarna Vasantrao, Deepak M. Vyas

Ayurlog: National Journal of Research in Ayurved Science- 2018; (6)(4): 1-8 